\title{
Study on the Influence of Snow Melt Water in Tianshan Mountains on the Water Filling of Yili No. 1 Mine and the Prevention of Water Hazards
}

Lin Feng ( $\sim$ fenglin10001@163.com)

China University of Mining and Technology https://orcid.org/0000-0001-7552-6080

\section{Yajun Sun}

China University of Mining and Technology

Chenghang Zhang

China University of Mining and Technology

Zhimin Xu

China University of Mining and Technology

\section{Zewen Yuan}

China University of Mining and Technology

\section{Bin Luo}

China University of Mining and Technology

\section{Xin Wang}

Hohai University

\section{Research Article}

Keywords: Yili No.1 Mine, Tianshan Snowmelt Water, Hydrophobic depressurization analysis, Mine Water Hazard Prevention

Posted Date: August 6th, 2021

DOl: https://doi.org/10.21203/rs.3.rs-703161/v1

License: (a) (1) This work is licensed under a Creative Commons Attribution 4.0 International License. Read Full License 


\section{Abstract}

Yili No.1 Mine locates opposite Tianshan Mountain in Yili Prefecture, Xinjiang. The main coal seams are No.3 and No. 5 coal seams. The alluvial strata cover the surface of the minefield in the piedmont of the Tianshan Mountains. Snowmelt in the Tianshan Mountains is an essential source of replenishment for surface water and alluvial strata in the basin. Due to the particular diagenetic environment and geological conditions, coal mining is mainly affected by weakly cemented sandstone aquifers on the roof and floor. To solve the water hazard problems of the No.3 coal roof and the No. 5 coal floor faced by the mine, we take the $1520 \mathrm{w}$ first mining face of Yili No.1 Mine as the research object. And through drilling and on-site water release tests, the threat of water inrush from the working face of the study area and the treatment plan are analyzed. The results show that the Quaternary aquifer in the study area is thin in thickness and fast in velocity. Therefore, it mainly flows through the site in the form of "slope transit flow", which has little impact on the roof water filling of the No.3 coal seams. In addition, the floor water discharge test proved that the sandstone aquifer of the No.5 coal seam floor has the characteristics of dredging. To eliminate the threat of water inrush during the next mining step in the mine, we proposed arranging an " $\mathrm{L}$ "shaped drainage project in the first working face. And the dredging effect was pronounced and can ensure the safety of mining. At the same time, it has essential reference significance for the mining work of other similar mines in the western region.

\section{Introduction}

In recent years, as the centre of gravity of coal mining in China has shifted westward, the proportion of coal production in the western region has increased year by year. According to incomplete statistics, coal production in western provinces in 2015 exceeded 2 billion tons, about $60 \%$ of the country's total production (Research Group of National Key Basic Research Program of China). However, due to the different coal-forming ages and the different natural geographical environments(Wang 2013; JIN et al. 2014), the coal-bearing strata in the western region have apparent characteristics such as late forming age and poor diagenesis(LIU and SUN 2019). These characteristics are very different from those of the Eastern Carboniferous-Permian coal-bearing strata(WANG et al.2019; YAO and WANG 2020).

In response to the above problems, some scholars have done relevant research. Scholars such as Yang Tianhong (ZHAO et al. 2015) studied the plastic strain energy and plastic deformation changes of weakly cemented sandstones with different particle sizes in the western mining area through triaxial cyclic loading-unloading experiments under different stress paths. Ren Huaiqiang (REN et al. 2008) analyzed the characteristics of sandstone micro-reservoir in the Turpan-Hami Basin through the Chase image analysis system. Sang Shuxun (SANG et al. 2001) studied the pore structure characteristics of low-grade coal reservoirs in the Turpan-Hami Basin. However, because of water inrush and mud inrush, significant ground subsidence, and large water inrush in the western coal development process, the mining experience summarized in the eastern mining area is no longer fully applicable to the west region (S. et al. 2017; YAO et al. 2020). 
Therefore, in-depth study of water prevention and control issues in western coal mining, especially the characteristics of water hazards and key water prevention technologies under special hydrogeological conditions in the west, has an essential guiding role in ensuring safe production in mines. At the same time, it also contributes to the realization of the western development strategy (XU et al. 2017).

\section{The hydrogeological conditions of the mine and the main problems}

\section{Hydrogeological conditions of the mine}

Yili No. 1 Mine is located $30 \mathrm{~km}$ south of Qapqal Xibe Autonomous County, Ili Kazakh Autonomous Prefecture, Xinjiang (Figure 1). The mine field situates on the front slope of Qapqal Mountain and the alluvial plain in the lli Basin. The terrain is high in the south and low in the north. The south is a hilly area with solid topography. The runoff conditions of the snowmelt water in the Tianshan Mountains are good, and the "slope transit flow" in front of the mountains flows through the site, resulting in complicated hydrogeological conditions in the study area.

\section{The main problems faced by the Yili Coal mine}

The study area locates in the middle and upper part of the piedmont alluvial fan of the Tianshan Mountains, with a stratum slope of 2\$凶4.5区. During the snowmelt period from March to May, snowmelt water is an essential nutrient source for the Quaternary aquifer. Under the action of gravity, the water flows from a higher place to a lower position and flows through the study area in the form of a slope transit flow (YUAN 2019). According to the drilling data, the main mining coal seams have insufficient roof bedrock thickness and low surrounding rock strength(Figure 2). The water-conducting fractured zone can easily lead to the Quaternary unconsolidated aquifer. Therefore, affected by the "slope transit flow" formed by the snowmelt in the Tianshan Mountains, roof water inrush accidents of the No.3 coal seam are incredibly prone to occur. Furthermore, it is possible to flood into the working face of the No. 5 coal seam through the fissures, which will cause more severe problems. At the same time, the aquifer of the No. 5 coal seam floor is a confined aquifer with strong water content, and it is also susceptible to the threat of water inrush from the floor during the mining. The existence of hidden water hazards in the coal seam roof of the No.3 and No.5 has severely restricted the large-scale development and construction of the mine and safe production.

\section{Analysis of Water Inrush Threat in 1502w Working Face}

To analyze the threat of water inrush in the study area, we constructed a total of 7 boreholes near the 1502w working face (Figure 3). The borehole of Q4, Q5 are exploration holes for the roof of the No.3 coal seam, and the borehole of FS1, GC1, FS3, FS4 and GC2 are exploration holes for the floor of the No.5 coal seam.

\section{Water-filling analysis of the roof aquifer of No.3 coal seam}


To verify the water-resistance of mudstone, we conducted a water release test. During the experiment, Q5 was used as a drainage well to drain the water in the Quaternary aquifer. And observing the water level changes of the sandstone aquifer of No.3 coal seam roof in the study area through Q4. The drainage test process is shown in Figure 5.

According to the flow-time (Q-t) relationship curve and the water level-time (h-t) relationship curve in Figure 5 , the water discharge rate was stable at about $4.5 \mathrm{~m}^{3} / \mathrm{h}$ during the water discharge test. However, the water level of the sandstone aquifer on the roof of the No.3 coal seam almost unchanged. Therefore, the bottom mudstone of the Quaternary System can effectively block the supply of the Quaternary aquifer to the sandstone aquifer of the No.3 coal roof and has good water resistance. In summary, the slope crossing current poses a minor threat to mine water filling and will not cause catastrophic water inrush accidents.

\section{Analysis on the Threat of Water Inrush from the Floor Aquifer of No.5 Coal Seam}

The lithology of the aquifer in the No.5 coal seam floor is dominated by gravel-bearing coarse sandstone mixed with fine sandstone and argillaceous loose cement. The average thickness of the aquifer is $10.60 \mathrm{~m}$, and it has a high confined water head, which is the main floor water-filling factor for mining No.5 coal seam. The boreholes FS1, GC1, FS3, FS4 are the drainage holes for the water drainage test, and borehole GC2 is used to observe the water pressure changes in the aquifer. The total flow rate of the water drainage test is stable at about $80 \mathrm{~m}^{3} / \mathrm{h}$, and the test duration is about 96 hours. The cumulative drainage water volume is approximately $8200 \mathrm{~m}^{3}$. We calculated that the unit water inflow in the study area is $0.013 \varangle 0.127 \mathrm{~L} / \mathrm{s} \cdot \mathrm{m}$, and the permeability coefficient is $0.119 \otimes 0.520 \mathrm{~m} / \mathrm{d}$ by the calculation method of hydrogeological parameters in the principles of groundwater dynamics (WHITAKER S. 1986). According to the regulations in the relevant coal mine water prevention and control (Table 1) (State Administration of Coal Mine Safely 2018), the study area belongs to complex hydrogeological conditions, and No.5 coal floor aquifers are of medium water richness.

\section{Tab.1 Aquifer Water Abundance Classification Table}

\begin{tabular}{|ll|}
\hline Classification & $\mathrm{q}(\mathrm{L} /(\mathrm{s} \cdot \mathrm{m}))$ \\
\hline Weak water richness & $\mathrm{q} \leq 0.1$ \\
\hline Medium water richness & $0.1<\mathrm{q} \leq 1.0$ \\
\hline Strong water richness & $1.0<\mathrm{q} \leq 5.0$ \\
\hline Extremely strong water-rich & $\mathrm{q}>5.0$ \\
\hline
\end{tabular}

Based on China's previous mining experience, an empirical formula suitable for the water inrush risk assessment of coal mine floors in my country has been formed-the water inrush coefficient method(Qiang 2012). 
$T_{s}=\frac{\mathrm{P}}{M}$

$\mathrm{T}_{\mathrm{S}}$ is the water-inrush coefficient for aquifers below the coal layer floor-MPa/m;

$\mathrm{P}$ is the aquifer pressure-MPa;

$M$ is the effective aquiclude thickness of floor $-m$.

We calculated the water inrush coefficient of the No. 5 coal seam floor in the study area through the above formula (Table 2). When the water inrush coefficient is greater than or equal to $0.06 \mathrm{MPa} / \mathrm{m}$, the study area has a higher risk of water inrush(State Administration of Coal Mine Safely 2018). Under the influence of water pressure and mining damage, it is straightforward to break through the floor water barrier and cause water damage accidents. Therefore, we must take water prevention measures to prevent the occurrence of water disasters.

Tab.2 Calculation results of water inrush coefficient of No. 5 coal seam floor (YUAN 2019)

\begin{tabular}{|llllll|}
\hline Drilling number & FS1 & FS2 & FS3 & FS4 & GC2 \\
\hline Water barrier thickness $(\mathrm{m})$ & 19.83 & 15.33 & 17.5 & 16.33 & 18.51 \\
\hline Water pressure $(\mathrm{MPa})$ & 1.34 & 1.27 & 1.16 & 1.15 & 1.18 \\
\hline Water inrush coefficient $(\mathrm{MPa} / \mathrm{m})$ & 0.067 & 0.083 & 0.066 & 0.070 & 0.064 \\
\hline
\end{tabular}

Evaluation on the drainage ability of the confined aquifer in the floor of No. 5 coal seam

Currently, there are two main methods for the prevention and control of mine water hazards in China. One is the grouting modification of the coal seam floor, and the other is the drainage for decreasing water pressure. However, the cost of the first method is relatively high. In addition, due to the gradual decline of the domestic coal industry (CHEN 2021), the use of large-scale grouting transformation projects will consume a lot of staffing and material resources, resulting in excessively high costs per ton of coal. However, on the one hand, the drainage method solves the water hazard of the mine, and on the other hand, we can also use the discharged water for industrial production of the coal mine. It turns the water hazards that threaten mine production into a favourable production factor, reducing the waste of water resources. And, the overall cost is much lower than the former.

Therefore, we analyzed the drainage of the confined aquifer in the study area through the water discharge test of the No.5 coal seam floor (Figure 3). According to the water pressure-time (P-t) curve of the water release test (Figure 6), the water pressure of the aquifer dropped significantly in a short time (about 36.6h). After stopping the drainage for 128 hours, the water level of the observation hole still had a water level difference of nearly $5 \mathrm{~m}$ from the initial water level, and the water level recovery time was significantly longer than the drainage time. 
In summary, it shows that although the confined aquifer permeability of the No.5 coal seam floor is good, its replenishment strength is not high, indicating that it has good dredging properties.

\section{Dredging engineering layout}

According to the previous section, the dredging properties of the No.5 coal seam floor's confined aquifer is good. Then we can eliminate the threat of water inrush after proper dredging before mining. However, the discharged water gushes out with many grey-white and grey-yellow sand particles (Figure 7). Refer to the water release test of Jurassic weakly cemented sandstone aquifer in the Dananhu mining area in Xinjiang (CUI 2017), which shows that the rock mechanics strength of the floor rock in the study area is low. If a centralized drainage engineering arrangement is adopted, it is straightforward to cause the cemented material in the stone to be dissolved and taken away by the water flow. As a result, the pore structure of the rock changes, and the water storage and permeability of the aquifer increase accordingly.

Therefore, to ensure the subsequent safe mining and eliminate the hidden danger of pressurized water inrush from the 5th coal floor, an "L" -a shaped project to expand the scope of dredging was adopted (Figure 8). We extend the water drainage boreholes to the periphery appropriately to form adequate drainage of the entire area and avoid aggravating the fragility of the floor of the study area.

As shown in Figure 8, the boreholes FS5, FS6, FS7, FS8, FS9, FS10, and FS12 are arranged for water discharge. And observe the water level changes through GC2 and GC3 boreholes. After dredging, the water pressure of the No.5 coal floor confined aquifer stabilized at $0.33 \mathrm{MPa}$, and the water inrush coefficient dropped to 0.018 . Significantly reduce the threat of water inrush.

During the dredging process, the aquifer's water pressure-time (P-t) curve (Figure 9) shows that the water pressure at the $1502 \mathrm{~W}$ working face drops rapidly, and the effect is pronounced. The $1502 \mathrm{~W}$ working face was completed in mid-December 2018. There was no water inrush during the mining period, indicating that drainage can effectively solve water damage to the coal floor.

\section{Conclusion}

In summary, because of the roof and floor water inrush problem faced by the first mining area of Yili No.1 Mine in Xinjiang, the focus is on the analysis and research of the hydrodynamic conditions of the special Tianshan snow meltwater in the western Quaternary aquifer. The field water release test shows that The slope was crossing current poses a minor threat to mine water filling and will not cause catastrophic water inrush. It has a significant reference value for the hydrogeological survey of similar mines in the surrounding area.

In addition, in response to the threat of water inrush from the weak cement floor of the No.5 coal seam, a project of arranging an "L" shape on the bottom of the study area was proposed to expand the scope of dredging and complete the experience of safe mining in the study area. It is also for other mines in the west with similar conditions. 


\section{Declarations}

Author Contributions:Conceptualization, L.F. and Y.S.; methodology, Y.S., C.Z.; validation, L.F.,C.Z.; formal analysis, C.Z., B.L., Z.X. and Z.Y.; investigation, L.F., Z.Y. and X.W.; writing-original draft preparation, L.F. and C.Z.; writing-review and editing, Y.S.; visualization, L.F., C.Z., X.W. and Z.Y.; supervision, Y.S.; project administration, Y.S.; funding acquisition, Y.S. All authors have read and agreed to the published version of the manuscript.

Funding: This research was funded by the National Key Research and Development Program of China (No. 2017YFC0804101/No. 2019YFC1805400) and the National Natural Science Foundation of China(No. 41772245).

Acknowledgments: The authors would also like to acknowledge the anonymous reviewers for their detailed comments that helped to improve this study.

Conflicts of Interest: The authors declare no conflict of interest.

\section{References}

Research Group of National Key Basic Research Program of China(2013CB227900) (Basic Study on Geological Hazard Prevention and Environmental Protection in High-Intensity Mining of Western Coal Area).Theory and method research of geological disaster prevention on high-intensity coal exploitation in the west areas. Journal of China Coal Society,2017,42(2):267-275(In Chinese)

WANG Shixin(2013)Geological and Tectonic Evolution Accumulating-Formating Rule in the Fatures and Coal Southern Margin of Turpan-Hami Basin囚Xinjiang. (Doctoral dissertation, Jilin University). (In Chinese)

JIN Xiang-lan, ZHANG Hong(2014)Jurassic coal system in the Ordos Basin. Journal of China Coal Society, (S1),191-197. (In Chinese)

LIU Qin, SUN Yajun, XU Zhimin, WANG Xin, ZHANG Chenghang, YAO Minghao(2019)Pore media characteristics of Jurassic weak cemented sandstone and its significance for water-preserved coal mining. Journal of China Coal Society, 44(03):858-865. (In Chinese)

SUN Lihui, JI Hongguang, YANG Bensheng(2019)Physical and mechanical characteristic of rocks with weakly cemented strata in Western representative mining area. Journal of China Coal Society, 44(03),866874. (In Chinese)

WANG Shuangming, DUAN Zhonghui, MA Li, ZHANG Yuping(2019)Research status and future trends of geological assurance technology for coal green development in Western China. Coal Science and Technology,47(02):1-6. (In Chinese) 
YAO Qiangling, TANG Chuanjin, LIU Zichang(2020)Discussion on coal and water co-mining in ecologically fragile mining areas in western China. Coal Science and Technology, 1-7. (In Chinese)

WANG Shuangming, SHEN Yanjun, SUN Qiang, HOU Enke(2020)Scientific issues of coal detraction mining geological assurance and their technology expectations in ecologically fragile mining areas of Western China. Journal of Mining And Strata Control Engineering, 2(04):5-19. (In Chinese)

ZHAO Yong-chuan, YANG Tian-hong, XIAO Fu-kun, WANG Hong, LIU Gang, ZHENG Xi, ZHOU Jing-ren, SHEN Zhi-liang(2015) The variation law of plastic strain energy of western weak cemented sandstone during cyclic loading experiment. Journal of China Coal Society, (08),1813-1819. (In Chinese)

REN Huaiqing, LIU Jinhua, YANG Shaochun, HE Yong, LI Honghu, DAI Lei(2008) Sandstone reservoir microscopic characteristics of braid delta of Hongtai area in Tuha Basin. Journal of China University of Petroleum(Edition of Natural Science), (05),12-17. (In Chinese)

SANG Shuxun, QIN Yong, FAN Bingheng, JIANG Bo, FU Xuehai, ZHANG Hua, XU Lei(2001)Features of Low Rank Coal Reservoir in Limnic Basins, Journal of China University of Mining \& Technology, (04):21-25. (In Chinese)

Qiang S., Zhang, J., Qiang, Z., \& Xu, Z.(2017)Analysis and prevention of geo-environmental hazards with high-intensive coal mining: a case study in china's western eco-environment frangible area. Energies, 10(6), 786-.

YAO Qiang-ling, TANG Chuan-jin, LIU Zi-chang (2020) Discussion on coal and water co-mining in ecologically fragile mining areas in western China. Coal Science and Technology:1-7. (In Chinese)

XU Zhi-Min, Gao Shang, Sun Ya-jun, Cui Si-yuan, Zhang, Meng-fei, et al.(2017)A study of conditions of water bearing media and water dynamics in typical jurassic coal rich regions in western China. Journal of China Coal Society. (In Chinese)

YUAN Zewen (2019) Study on Hydrogeological Characteristics and Water Disaster Prevention Technology of Yili No.1 Mine. (Doctoral dissertation, China University of Mining Science and Technology). (In Chinese)

WHITAKER S. 11986 BFlow in porous media IXA theoretical derivation of Darcy's law. Transport in Porous

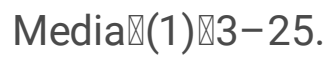

State Administration of Coal Mine Safely (2018) Detailed rules for water control in coal mines. Beijing: Coal Industry Publishing House of China.

Qiang W, Suqi Z, Shuning D et al. (2012) Dissection of main technical points in "Coal Mine Safety Regulations(water control part)" modification. Coal Geol China 24(7):34-37 (in Chinese) 
CHEN Fu, YU Haochen, BIAN Zhengfu, YIN Dengyu (2021) how to handles the crisis of coal industry in China under the vision of carbon neutrality. Journal of China Coal Society: 1-14 (In Chinese)

CUI Siyuan (2017) Study on Hydro-dynamic Field and Media Characteristics of Weakly-Cemented Jurassic Aquifer in Dananhu Area. (Doctoral dissertation, China University of Mining Science and Technology). (In Chinese)

\section{Figures}

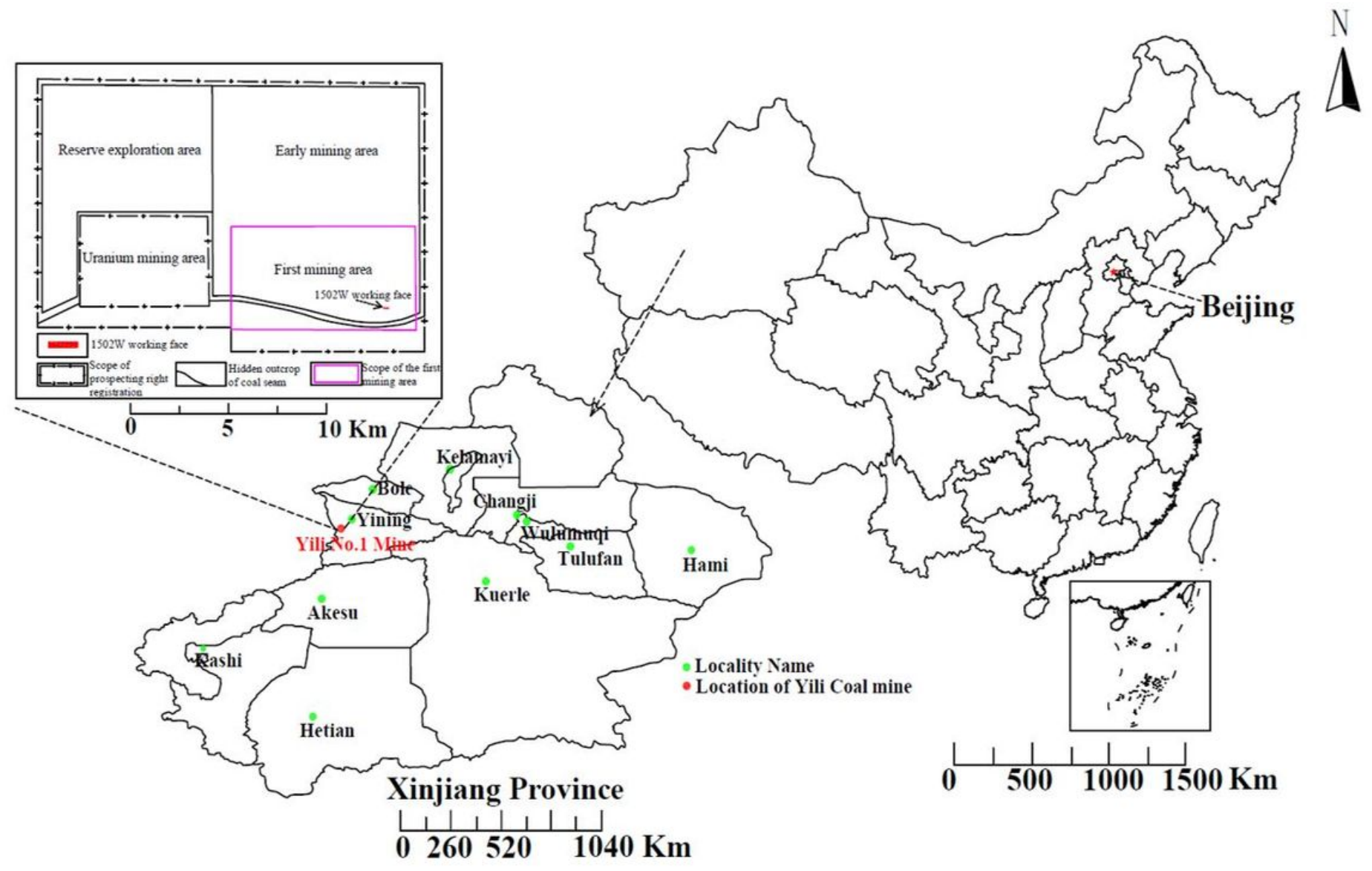

Figure 1

Schematic diagram of the location distribution of the study area 


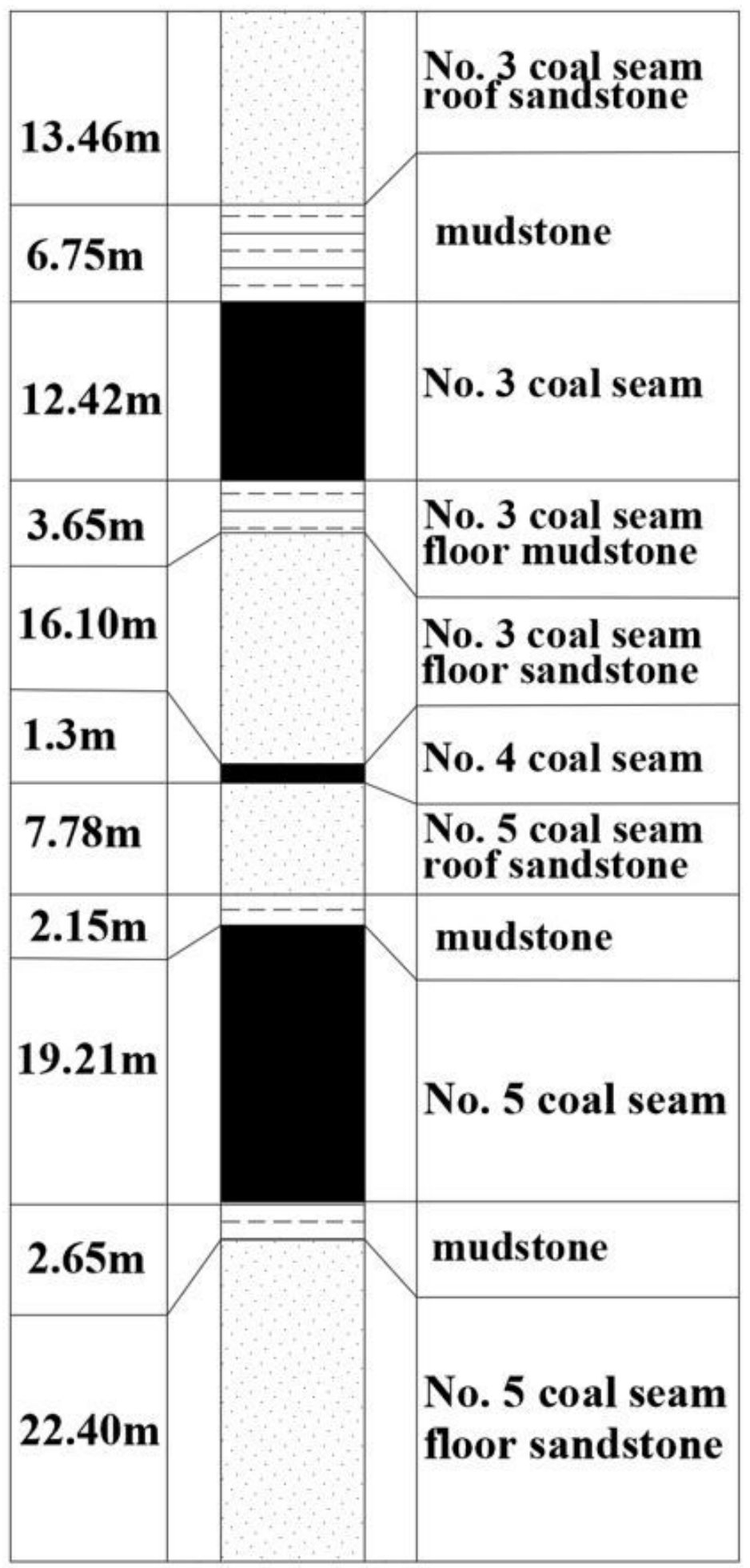

Figure 2

Schematic diagram of the stratum structure of the coal seam in the study area 


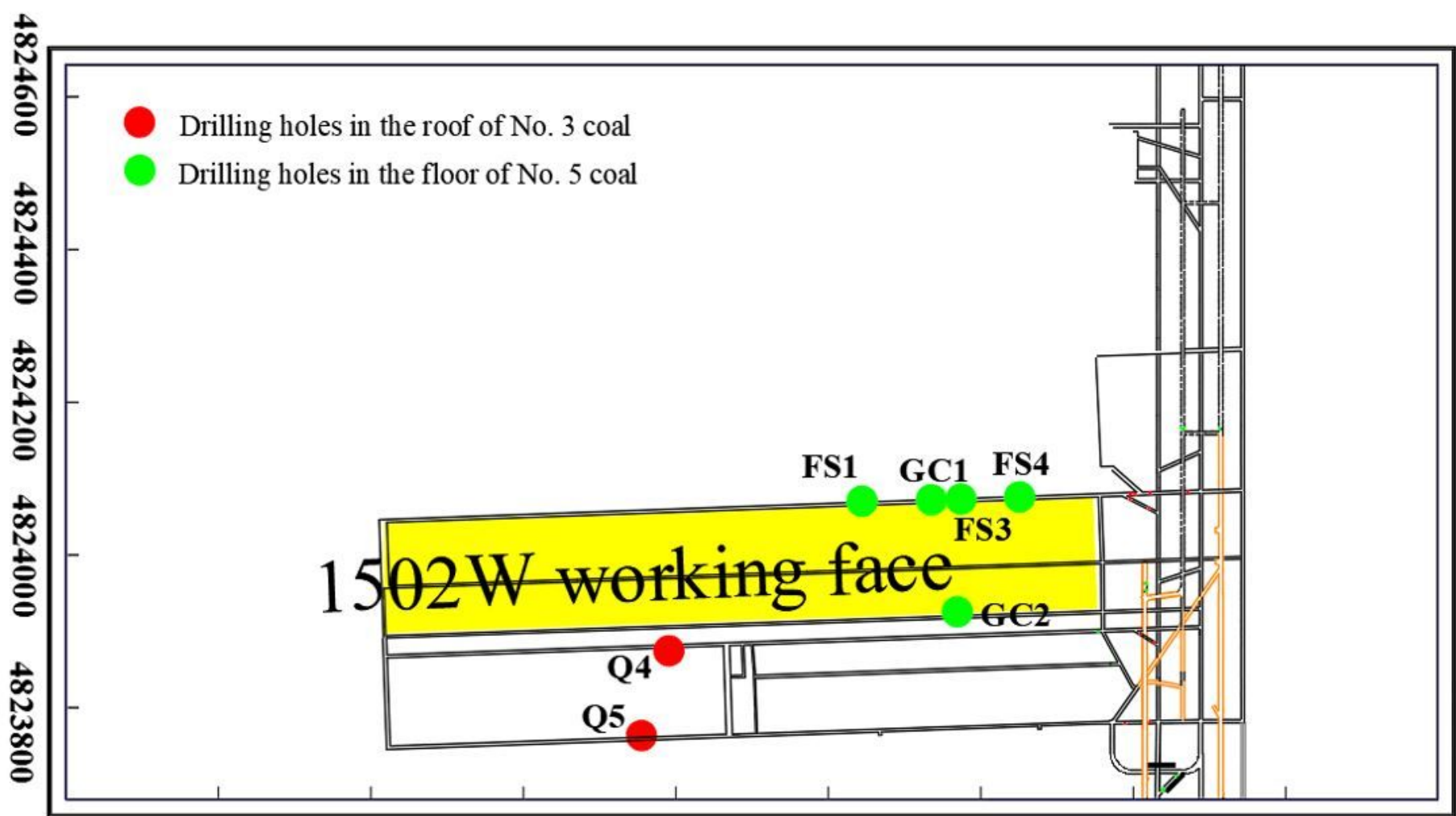

$144956001449580014496000144962001449640014496600 \quad 1449680014497000$

Figure 3

Layout of exploration boreholes in the study area

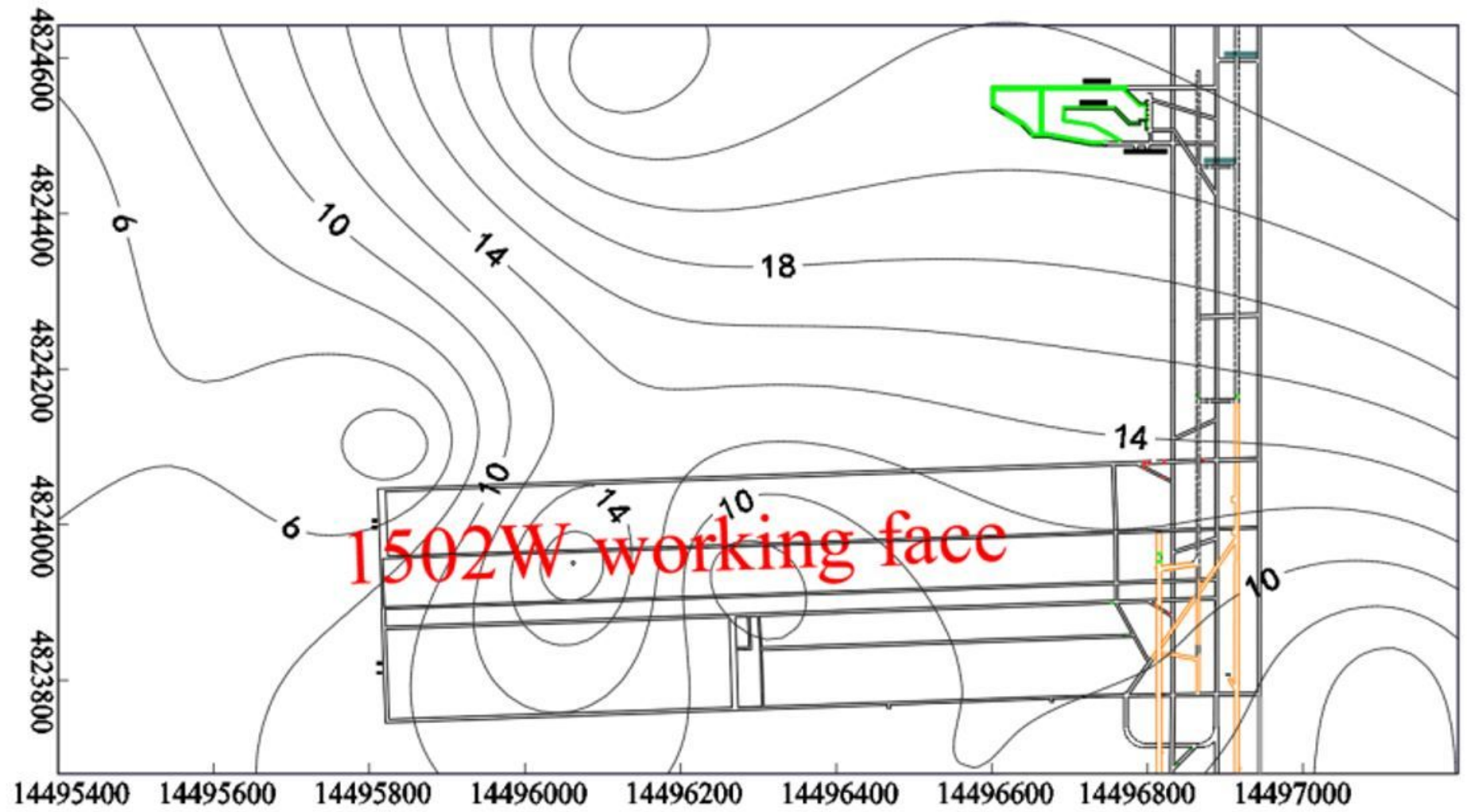


Figure 4

Contour map of mudstone thickness

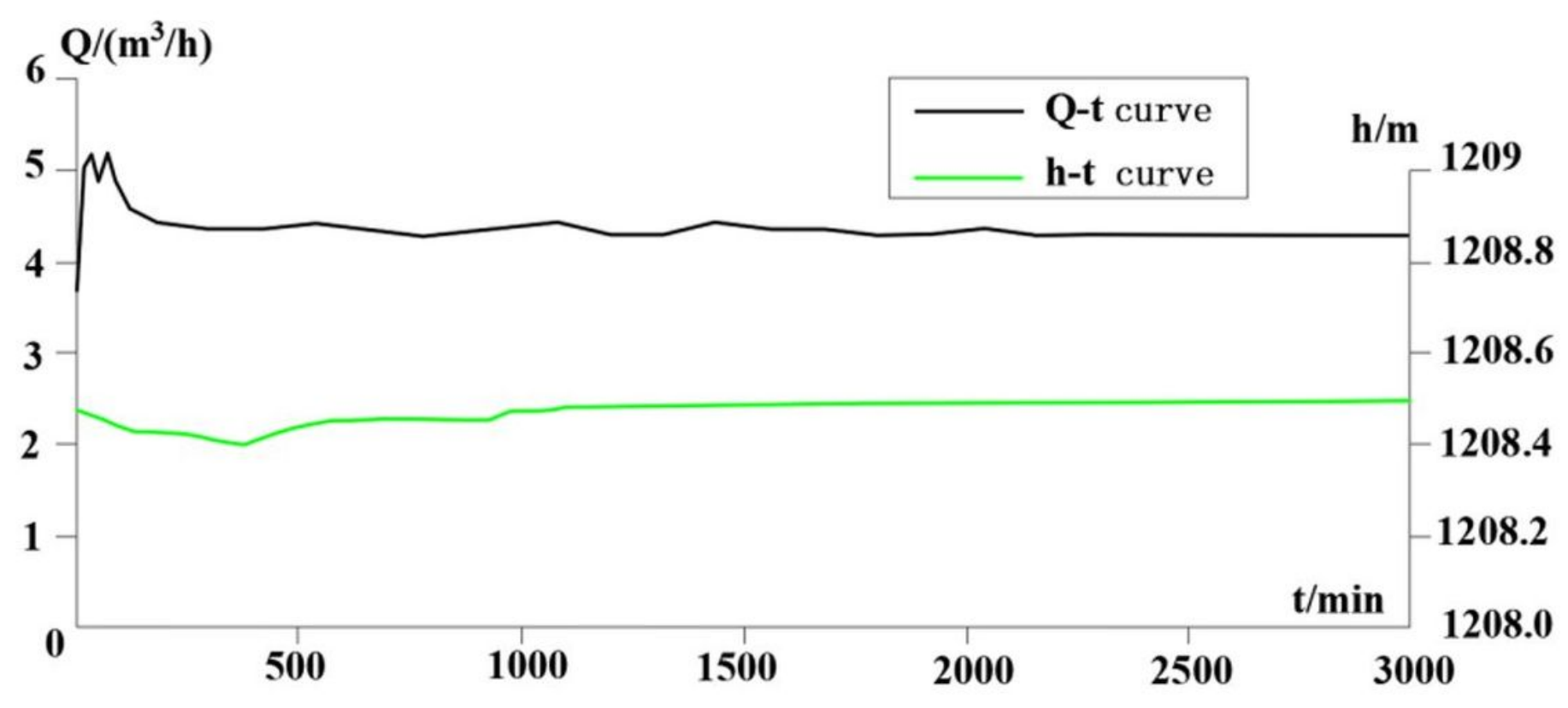

Figure 5

Curve diagram of water discharge test process for roof aquifer of No. 3 coal seam 


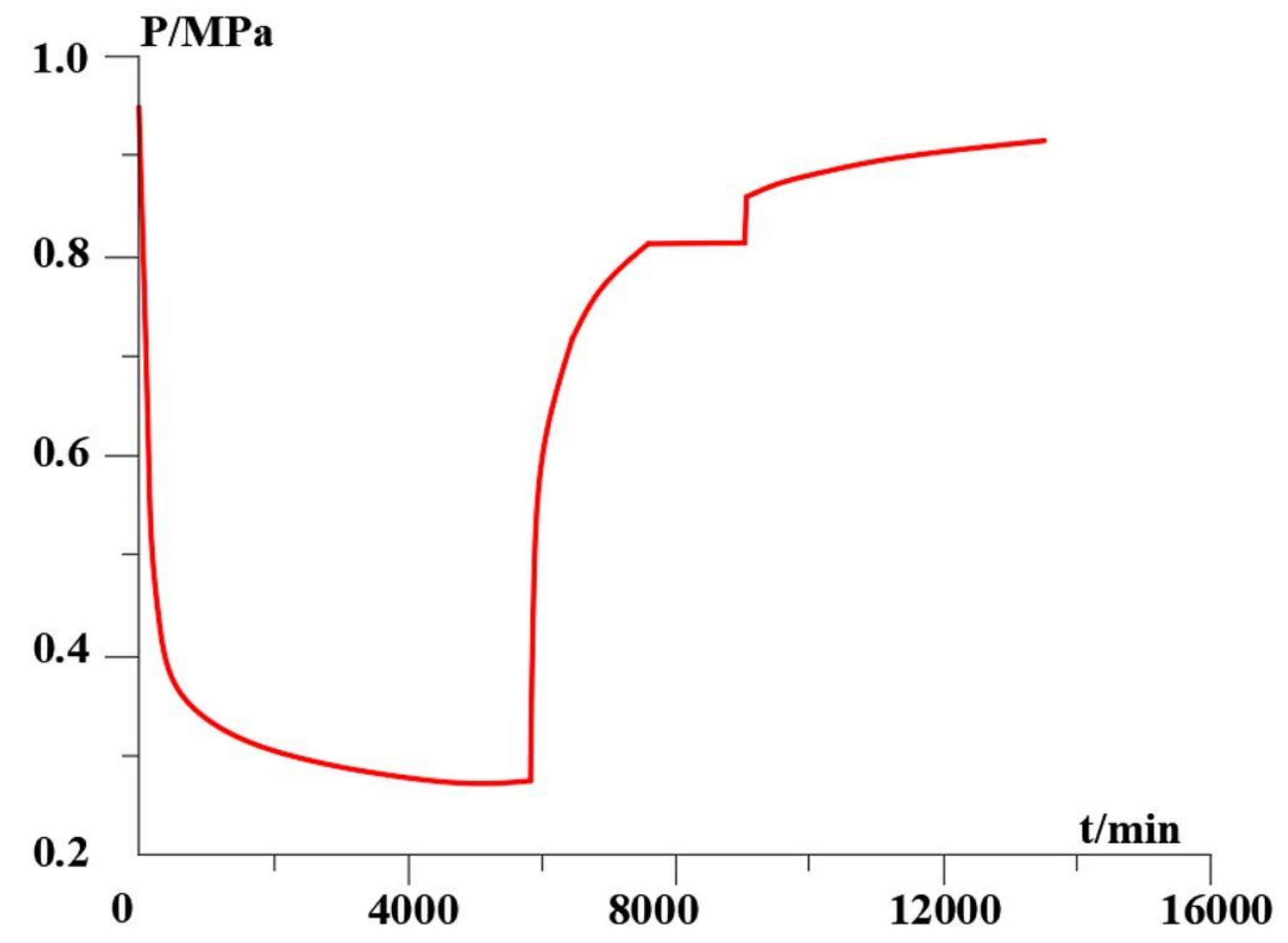

Figure 6

Water pressure change curve 


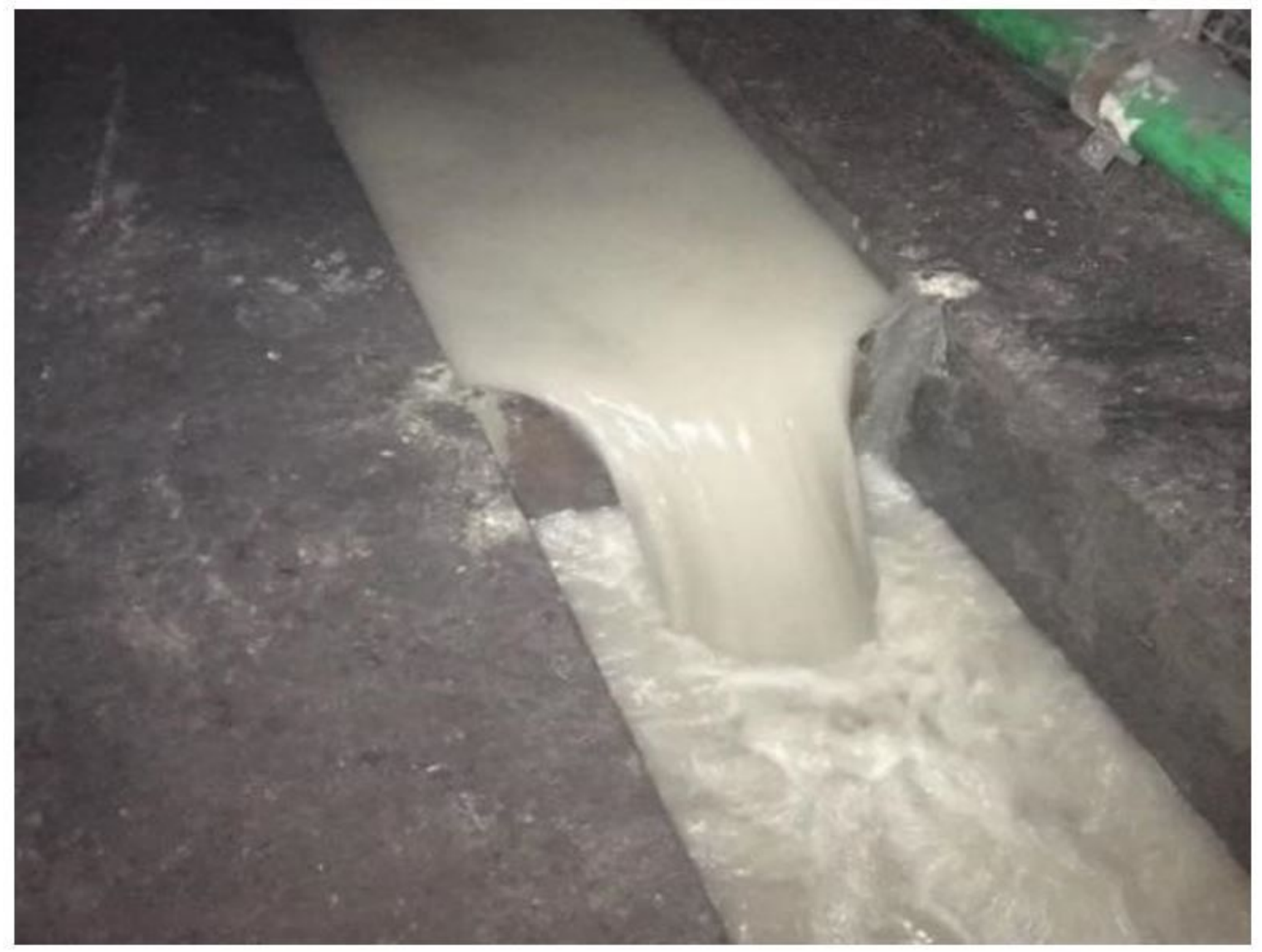

Figure 7

water with a lot of off-white and grey-yellow sand grains (YUAN 2019) 


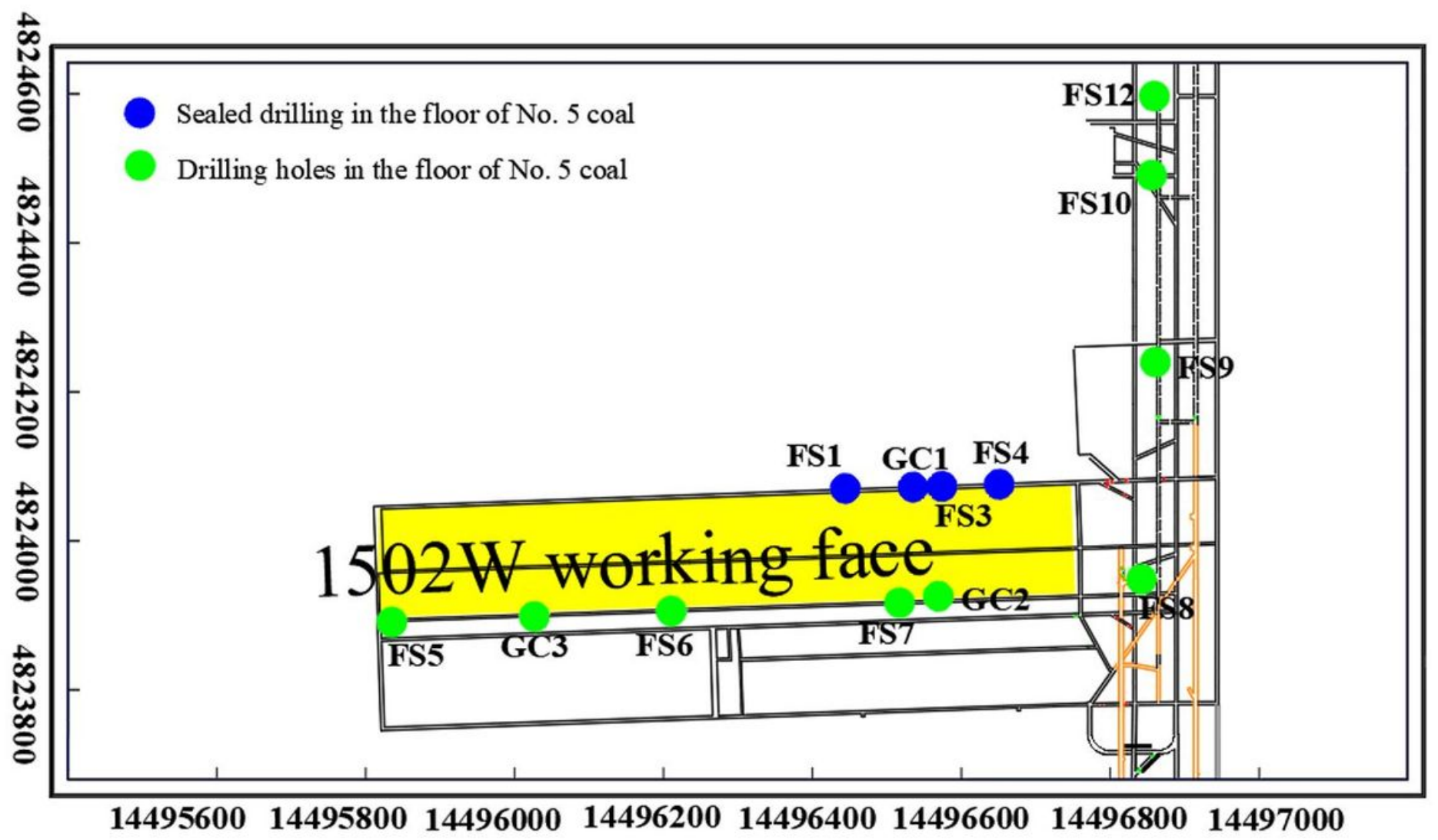

Figure 8

Schematic diagram of " $L$ "-shaped dredging project layout 


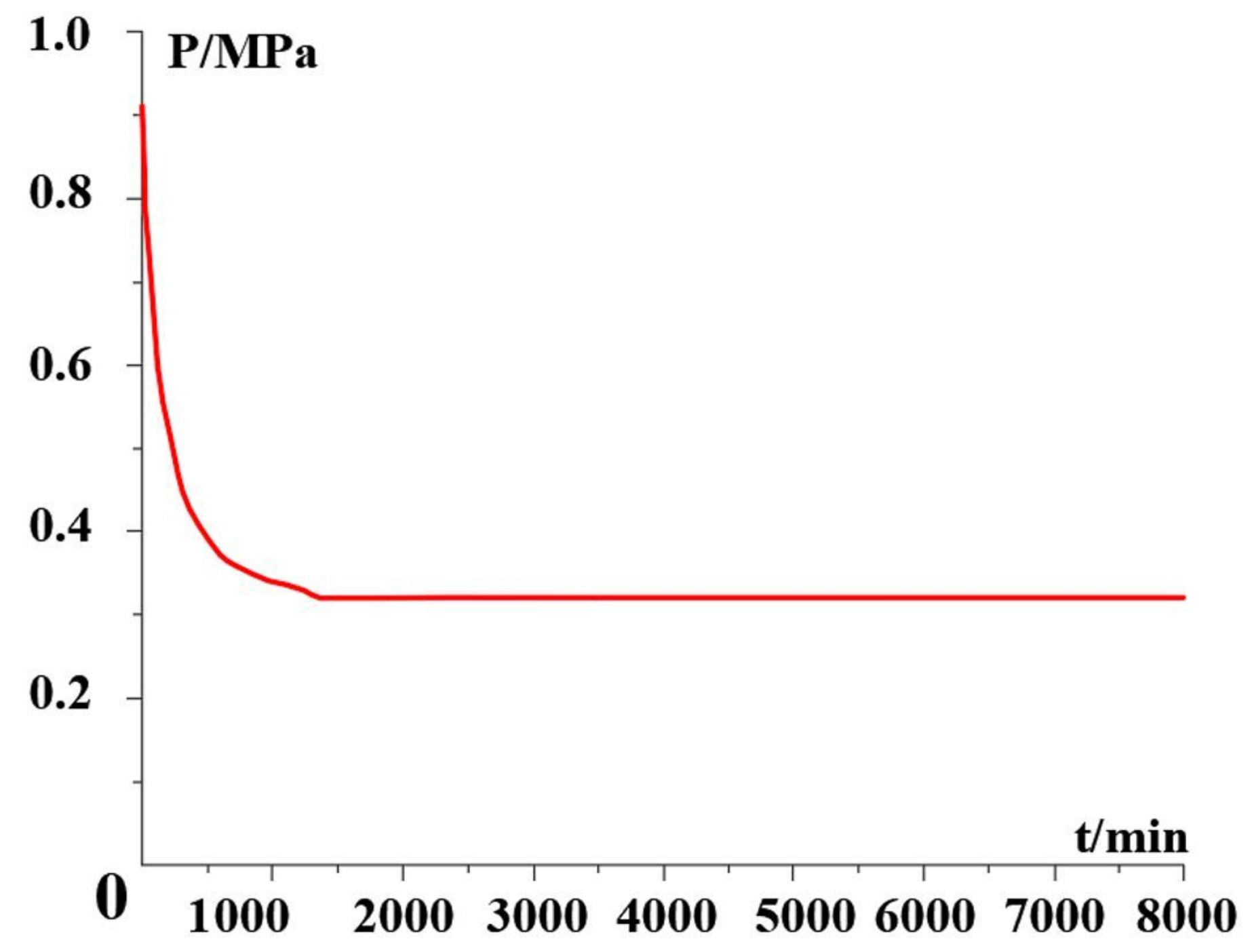

Figure 9

The layout of water discharge holes and the change curve of water pressure in the aquifer 